\title{
SLAVIC LANGUAGES IN CONTACT, 4: TURKIC IN SLOVAK - A SHORT NOTE
}

Keywords: Slavic languages, Slovak language, Turkish language, etymology, areal linguistics

\begin{abstract}
Slovak has never had especially intense contacts with Turkish or any other Turkic language. This author tries to show that loanwords called "Turkisms in Slovak" nevertheless call for more attention and research than one might initially think as well as that, indeed, there possibly exist a few words borrowed directly from Turkish into Slovak. These words may, at least sometimes, reflect an old colloquial pronunciation variant in the speech of Turkish soldiers and are, thus, a Slovak contribution to investigation into Turkish linguistic history.
\end{abstract}

1

When one looks through publications concerning Turkish (and, possibly, Turkic) influence on Slovak one may wonder that relatively numerous Turkic borrowings in that language are known, resulting from the Ottoman presence in southern Slovakia in the 16 th and 17 th centuries. As a matter of fact, the Ottoman troops only occupied a number of fortresses, castles or towns, but no mass migrations of Anatolian peasants are known who would have settled down for good there, as was the case in Bulgaria and Macedonia. Similarly, no mass conversions to Islam were observed as we know them from the history of Bosnia. Thus, the command of Turkish among Slovaks must have been so limited that few of them could have had contact with spheres of Turkish life distinct from the military and administration. 
Some authors, thus, rightly characterize Turkish words in Slovak as exotisms and situate them on the outskirts of the Slovak vocabulary. ${ }^{1}$

\section{2}

Three groups of words commonly called "Turkic loanwords" are to be reckoned with in Slovak:

1. Words borrowed in the Proto-Slavic epoch (e.g. tovar 'ware, commodity', torba 'bag'; see Blanár 1962: 77). - There is some disagreement as to which words in the Proto-Slavic lexicon are actually borrowings from Turkic. Apart from this fact, their reflexes in modern Slovak are all just reflexes of Proto-Slavic words. Those Turkic loanwords were foreign and new to speakers of Proto-Slavic but then they were adaptated and in the course of time passed down as an inheritance along with all other Proto-Slavic words. Put differently, they are all just Slavic words extant from the Slavs' own protolanguage. I fail to see why they should be regarded as "Turkic words in Slovak".

2. Words borrowed through intermediary languages. - It is an absolute certainty in modern etymology that loanwords should be classified according to their direct source. ${ }^{2}$ Thus, Slovak donchuan [-nx-] 'ladies' man, womaniser' reflects the original Spanish pronunciation of Don Juan [-nx-] while Polish donżuan [-nž-] id. reflects the French mediatory word, that is: Slovak donchuan $<$ Spanish; Polish donżuan < French $<$ Spanish. This simple etymology clearly shows that classification by the ultimate source would blur the difference between the Slovak and the Polish word, by alleging that both were Hispanisms. A similar case is that of Slovak dohán $(\dagger)$ 'tobacco' < Hungarian dohány id. < Turkish duhan '1. smoke; 2. tobacco' (< Persian < Arabic, see Králik 2015: 129) - here neither the phonetic aspect (Slovak - $O$ - and -á-) nor the semantic one (no 'smoke' in Slovak) can easily be explained if the Slovak word is classified as a Turkism while understanding it as a Hungarism removes almost all doubts. ${ }^{3}$ Even a cursory examination of

1 "Exotizmy majú v slovnej zásobe jazyka miesto na jej samom okraji” (Majtán 1987: 229); "Turcizmy, hebrejizmy a arabizmy sú na okraji slovnej zásoby a zaradujú sa medzi exotizmy" (Kopecká et al. 2011: 49).

2 Cf. "In der etymologischen Forschung gilt das Prinzip der direkten Etymologie." (Leschber 2011: 33).

3 An unclear aspect, however, is Slovak $-n$ in lieu of ${ }^{*}-\check{n}<$ Hungarian $-\dot{n}<-n y$. The palatal pronunciation of a word-final $-n$, that is $-n$, is a Middle Hungarian feature. Its reflexes in Slovak are of two types (esp. in older and dialectal sources), that is $-\dot{n}$ and $-n$. In most cases, the palatality remains unchanged, e.g. Slovak gerheň 'a kind of corn cake' < Hungarian görköny; Slovak kapitán̆ 'captain' < Hungarian kapitány (Rocchi 1999: 105, 129). Alternations are also known, as is the case with Slovak igazolván igazolvaň (!, no *án̆) 'identity card' < Hungarian igazolvány (ibid. 127). And cases of total dispalatalization can be found as well, for instance, Slovak dolomán 'man's gala jacket' < Hungarian dolmány (ibid. 80). No clear rules regulating this change seem to have been formulated thus far. 
loanwords called "Turkish" or "Turkic" in Slovak publications shows that the lion's share of them entered Slovak through one or a few intermediary languages. In view of the concept of direct source, one feels obliged to remove them from the "Turkic list" into other indexes of loanwords in Slovak. ${ }^{4}$

3. Terms called "exotisms" and "historisms", that is designations of various reallife elements in the Ottoman epoch, such as, for instance, turban 'turban', vezír 'vizier', janičiar 'janissary'. Indeed, it is prima facie possible that they were borrowed directly from Turkish. Possible, but not sure.

The turban was actually called tülbent in Turkish, and it is rather astonishing to claim that the Slovak distortion of the Turkish word is accidentally identical with, say, English or French, Polish or German, and so on, without any intermediation of these languages. Besides, the word is ultimately of Persian origin (that is, European languages $<$ ? Balkan languages $<$ Turkish $<$ Persian) so that it cannot just be called a Turkism.

Slovak vezir 'vizier' has a long vowel -í- whereas its Turkish equivalent has a short -i- (Ergenç 1995: 393: [ve'zIr] $]^{5}$. Actually, its Slovak reflex should have a short vowel, too. Is it a mere accident that its Hungarian counterpart has a long vowel: vezír id., just as Persian vazir [väzirr] and Arabic wazir [ưazirr]? ${ }^{6}$

Slovak janičiar 'janissary' displays an $a-a$ sequence and this is also typical of many European counterparts of this word. However, their Turkish etymon is yeniçeri, that is, it has an $e-e$ sequence. Again, is it credible that Slovak changed the Turkish vowels $e-e$ and lost the Turkish word-final vowel exactly in the same way as did many other languages but independently of them? Besides, can the Slovak

4 It is not always easy to decide whether a word was or was not borrowed via Hungarian. Rocchi (1999: 141) accepts mediation of Hungarian kapitánbasa (1597) for Slovak kaputanbaša (1786) - probably because of its consonants $-t-b$. The standard Ottoman Turkish etymon was kapudan paşa, a variant whose - $u$-very well matches the Slovak form but its consonants $-d$ - $p$ - do not. Now, it is a matter of criteria: are vowels more decisive than consonants or otherwise? Fortunately, the başa paşa alternation is very well known in Turkish and has even been discussed in the literature. The form kap(i)tan başa is attested in colloquial Turkish, too (so that mediation of Hungarian kapitánbasa was not necessary), e.g. Turkish kapitan başa 〈capitán basciá (1611) (Rocchi 2012: 105) kapitan başa 〈Capitan Bafcha〉 (1622) (M. Stachowski 2015: 601) = kaptan başa 〈qabtan basciah〉 (1650) (Rocchi 2011: 194). Thus, it seems fairly possible that Slovak kaputan baša reflects a Turkish colloquial pronunciation variant ${ }^{*}$ kaputan $\left(<{ }^{\star}\right.$ kapitan < kapitan) possibly used by some simple soldiers or other Turks without careful education. If this is correct, the Slovak word kaputanbaša actually can be regarded as a direct loan word from colloquial Turkish (not Ottoman!). (A funny paradox is that so many Hungarian borrowings have been classified as Turkish whereas the Turkish loanword ${ }^{*}$ kaputan başa was regarded as Hungarian).

This is an interesting example of the importance of such research: I unsuccessfully tried to find the variant kaputan, that is with -put-in some major dictionaries of older Turkish whereas forms with -pt- or -pud- are well attested. Turkologists will feel lucky with this colloquial Turkish find in Slovak.

5 With $[\gamma]$ rendering word-final spirantic pronunciation of the flap $[r]$ in Ergenç (1995).

6 Does the Italian notation 〈viscier〉 (1596) (Schweickard 2018: 989) suggest a long -i $\overline{-}$ - in 16thcentury Turkish? 
group -čia- reflect the Turkish monophthong -çe-? Rocchi (1999: 184) explains the Slovak word janičiar as a loan from Hungarian jancsár, and this etymology (at least partially) clears up the origin of the Slovak sequence -čia-.

That will probably suffice to convince the reader that even exotisms and historisms should not hastily be classified just as simple loanwords from Turkish.

Problems presented in [2] and [3] are actually typical of almost all philologies in Europe, Slovak undeniably being no exception. An informative methodological insight into what has been done thus far and what should be done in the future can be gained by comparing the current state of research in a specific philology with the discussion offered in Schweickard (2011: 231-239) and Urban (2015 passim).

Furthermore, lack of elementary Turkological training, with comparative and historical knowledge understood, causes various, sometimes curious mistakes. Let one example stand for all: The claim that "[T]he [Slovak] form beg comes from Turkish bey (in Arabic bek, and hence the Bosnian beg)" 7 actually is a sort of a carousel of mistakes - one cannot decide where to start with corrections. A cooperation of Slovacists (or Slavists) with Turkologists (and, possibly, representatives of some other linguistic disciplines) will be absolutely necessary to effect the purpose. Besides, combining linguistics with non-linguistic knowledge seems to offer most encouraging insights: cf. K. Stachowski, O. Stachowski (2016, 2017a, 2017b).

I am not going to enumerate and discuss mistakes here. Rather, I would like to suggest what we still need: (a) establishing for any Slovak word suspected of being a Turkish loanword whether it could or could not be borrowed from a language other than Turkish, (b) as well as, perhaps, checking its "prehistory" (is it a genuine Turkish word or a loanword into Turkish?). One would expect that such a procedure will correctly show "real Turkish loanwords", i.e., possible direct loanwords from Turkish into Slovak, and exclude all others. Another important methodological aspect is (c) looking after Turkish etymons in 16th and 17th-century sources of the Turkish language, possibly dialects, rather than in readily accessible modern 21stcentury literary dictionaries (on the history of this prerequisite see M. Stachowski 2018 passim). ${ }^{8}$

The same is of course also valid for non-Turkish Turkic. Words concerning data from Turkic-speaking republics of the former Soviet Union as, for instance, Slovak

"Forma beg je z tur. bey (v arabčine bek a odtial' bosenské beg)" (Blanár 1962: 82).

8 Even though this rule appears natural and self-evident it is more often than not ignored. One example only: the following etymologies: “yatağan ['yataghan'] > [Slovak] jatagán; yoğurt ['yoghurt'] > [Slovak] jogurt" (Džunková 2012: 27) display the modern letter 〈 ‘̆` which only signals that the preceding non-palatal vowel is pronounced long, that is respectively [iata:an] and [io'urt]. How could longness of a Turkish vowel have yielded $g$ in Slovak, that is Turkish [:] $>$ Slovak [g]? Modern forms cannot explain the phonetics of old borrowings. (Additionally, the long -á- in jatagán cannot be possibly traced back to the short Turkish - $a$ - either). 
bajdžarach 'pergelisol hill in Yakutia' or manat 'unit of currency in Azerbaijan' will probably rather result from transmission through Russian than from borrowing in direct Slovak-Yakut and Slovak-Azeri language contacts.

\section{References}

Blanár V. 1962. Otázka lexikálnych turcizmov v slovenčine. - Jazykovedný Časopis 13.1: 76-87. Džunková K. 2012. Turkické výpožičky v slovenčine. [unpublished]. Praha.

Ergenç İ. 1995. Konuşma dili ve Türkçenin söyleyişsözlüğ̈̈. Ankara.

Kopecká M. et al. 2011. Staršia slovenská lexika v medzijazykových vztahoch. Bratislava.

Králik L. 2015. Stručný etymologický slovník slovenčiny. Bratislava.

Leschber C. 2011. Lehnwege einiger Orientalismen und Wörter eurasischer Herkunft im Rumänischen und den sonstigen Balkansprachen. - Studia Etymologica Cracoviensia 16: 33-61.

Majtán M. 1987. Pomenovanie reálií z tureckého (moslimského) a židovského prostredia v staršej slovenčine. - Studia Academica Slovaca 16: 229-244.

Rocchi L. 1999. Hungarian loanwords in the Slovak language. [vol. 1: A-K]. Trieste.

Rocchi L. 2011. Il dizionario turco-ottomano di Arcangelo Carradori (1650). Trieste.

Rocchi L. 2012. Il "Dittionario della Lingua Turchesca" di Pietro Ferraguto (1611). Trieste.

Schweickard W. 2011. Osmanismen in den europäischen Sprachen. Vorüberlegungen zu einem vergleichenden historischen Wörterbuch. - Lexicographica 27: 221-239.

Schweickard W. 2018. Il glossario italo-turco nel Viaggio di Terra Santa di Giovanni Francesco Alcarotti (1596). - Biffi M., Cialdini F., Setti R. (eds.). "Acciò che 'l nostro dire sia ben chiaro». [vol. 2]. Firenze: 983-992.

Stachowski K., Stachowski O. 2016. Possibly Oriental elements in Slavonic folklore. Kłobuk. Türk Dilleri Arastırmaları 26.2: 241-264.

Stachowski K., Stachowski O. 2017a. Possibly Oriental elements in Slavonic folklore. Mamuna. Studia Linguistica Universitatis Iagellonicae Cracoviensis 134.2: 97-102; 134.4: 289-304.

Stachowski K., Stachowski O. 2017b. Possibly Oriental elements in Slavonic folklore. Upiór Wampir. - Németh M., Podolak B., Urban M. (eds.). Essays in the history of languages and linguistics. Kraków: 643-693.

Stachowski M. 2015. Osmanisch-türkische Appellativa im Reisebuch von Adam Wenner (1622). - Ragagnin E., Wilkens J., Şilfeler G. (eds.). Kutadgu Nom Bitig. Wiesbaden: 593-607.

Stachowski M. 2018. Problemy metodologiczne z badaniem orientalizmów w języku polskim. - Studia Językoznawcze. Synchroniczne i diachroniczne aspekty badań polszczyzny 17: 303-314.

Urban M. 2015. The treatment of Turkic etymologies in English lexicography. Lexemes pertaining to material culture. Kraków. 
